\title{
Identifying the Level of Awareness on Value Management Practice amongst Construction Developers
}

\author{
N.S. Lop ${ }^{1}$, M.A.M. Apandi ${ }^{2}$, I.F.M. Kamar ${ }^{3}$, N.M. Salleh ${ }^{4}$, S. Mamter ${ }^{5}$, N.A.M. Hamdan ${ }^{6}$ \\ 1,2,3,4,5,6 Department of Quantity Surveying, Faculty of Architecture Planning and Surveying, UiTM \\ Perak, 32610 Bandar Baru Seri Iskandar, Perak, Malaysia.
}

\begin{abstract}
Construction Industry is one of the catalysts that enable such a nation economy to kept runs and grow from time to time. In this large and unique industry, the position of Architect, Engineer, Quantity Surveyor and Builders is the position that had been so familiar generally. Many of people do not aware with Value Management practice in Malaysia. Value Management may be described as a structured, analytical process for developing innovative holistic solutions to complex problems. The objective of this research is to identify the level of awareness on Value Management practice amongst Construction Developers. In this study, the General Manager, Professionals and Project Manager from 34 Developers Company registered under Real Estate and Housing Developers' Association (REHDA) in Kelantan State has been chosen as respondents. Quantitative methods have been used and 102 sets of questionnaire had been distributed where the returned was only 81 sets. The results indicate that most of the respondents did aware with the Value Management issues in Malaysia. Ultimately, this research paper hoped to contribute in the improvement of the implementation of Value Management in Malaysia especially amongst Developers.
\end{abstract}

\section{Introduction}

Construction Industry is the sector that commonly related to the sector that contribute to the growth of other sector in such a country. Construction industry provides physical development and infrastructure like new residential, roads, bridge, and towers thus, all sector require construction industry in providing the place or buildings to operate such work in a sector. Most of the sector involves in runs the economic growth will require construction industry to build up their office, factory and premises.

According to New South Wales Treasury [1] described that, Value Management as a structured, analytical process for developing innovative holistic solutions to complex problems. Jaapar [2] stated that, Value Management is a multi-disciplinary, team orientated, structured, analytical process and systematic analysis of function which seeks best value via the design and construction process to meet the client's perceived needs'. Typically, value management functions to ensure that such construction project will achieve value for money product without ignoring the clients need and requirements towards the project.

In Malaysia, value management was first introduced to the construction industry in 1986 which is almost 3 decade ago, but yet, the application of value management in Malaysia Construction Industry 
is still in its infancy [3]. Most of the parties involved in Malaysia construction industry do not implement the value management process even though the profession was introduced long time ago. Many researchers in Malaysia had carried out research regarding the application of value management in Malaysia.

Value management practice is not widely used in Malaysia even though it was first introduced in Malaysia construction Industry in 1986 [3]. Even though it had been more than 25 years of the value management introduction in Malaysia construction industry, the application of this profession is still at a low numbers. The value management terms it seems likely not to be involves in most of construction project due to lack of knowledge on its practice. Even though the studies of VM have found that the implementation of VM by the construction participants in Malaysia still at the infant stage, but the level of awareness amongst the specific construction participants is still not yet identified. Hence, a further research will be carry out in order to find out the level of awareness that affect to the level of application and practice of Value Management for the construction project by focusing at Kelantan State only. This research only focuses on the identifying level of awareness on Value Management practice (VM) amongst construction developers in Kelantan State.

\section{The Levels of Awareness on Value Management Practice}

Value Management (VM) is a structured, systematic and analytical process which seeks to achieve value for money by providing all the necessary functions at the lowest total cost consistent with the required levels of quality and performance. Additionally, it is a technique for improving client value in projects, products, processes and systems which has been internationally recognized for almost forty years [4].

Ong [5] stated that, VM has been widely practiced in countries like the USA, UK, Australia and Hong Kong, it is still not so in Malaysia due to the lack of knowledge and awareness of its existence and applications. VM also can be considered still at its infant stage in Malaysia as only a handful of construction projects have been known to apply VM so far by the construction parties.

According to Jaapar [2] in the research paper of value management study to the Malaysian construction industry, stated that, the implementation of value management in overall construction industry will be depending on the results of whether the application and partied value management is consistent with internationally practices and what had been experienced by the project that had been applying Value Management in their project.

As quoted from Che Mat [6] is his research paper of the challenges and potential of value management in local construction industry, he claimed that the significant contributions and tremendous amount of savings resulting from value management studies lead to its worldwide application especially in developed countries and many requires formal value management studies for their projects above certain budget. He adds that in Malaysia, Value Management application is still at infant stage. However, judging from the feedback that gathered from the Value Management road show in 6 major towns in Malaysia and Brunei towards the end of 1997, the respond were very encouraging and many have shown their interest to further understand this technique"[6].

Saifulnizam et al (1) in his research paper mentioned that, the level of awareness and appreciation of $\mathrm{VM}$ as an essential toolset for providing better value has developed sufficiently over time to the extent that the Institute of Value Management Malaysia (IVMM) was established in 2000 with support and encouragement from Government agencies such as the Professional Services and Development Corporation (PSDC).

Bowen [7] also stated that, the use of VM among South African quantity surveyors does not reach their reported levels of awareness of this management technique. He also stressed that, indeed, their awareness also appears to relate more to older understandings of value engineering, rather than to more contemporary developments of VM and its application.

Jaapar etl al. [8] in the result also confirmed that the majority (51\%) of the respondents did not practice the VM methodology in their working environment and a large number of organisations had 
no experience in any workshop in the application of VM study in the construction projects procured. She was also found that more than half of the projects (57\%) used in-house facilitators to facilitate the VM workshops rather than hiring an independent VM facilitator, it was also found that $63 \%$ of respondents did possess a good level of understanding towards the VM concept by the quality of feedback gathered from the questionnaire.

\section{Methodology}

This research collected data by hand questionnaire and distributed to the developer companies in Kelantan state. The survey has been carried out on the developers registered under The Real Estate and Housing Developers' Association (REHDA) by selecting overall developer's company available in Kelantan state to gather relevant data in this study. Overall of 34 developers registered under REHDA been chosen for the study and each of 34 companies will be distributed with three (3) sets of questionnaires. The targeted respondents are the top management and professionals of the company. Therefore, 102 sets of questionnaires have been distributed by hand which is 3 sets provided for each company making the overall respondents to be 102 . The numbers of returned questionnaires are 81 respondents.

The data were analysed using SPSS (Statistical Package for the Social Sciences) version 21 software to produce descriptive statistics. These results were presented in the form of tabulation. This research paper will guide the result obtain from the quantitative result to determine the research outcome to be parallel or not with the referred research paper. As the result is compared with the literature, the conclusion is made and the recommendation for the future research could be obtain.

\section{Results and Discussions}

\subsection{Demographic Background}

Table 1 : Years of company established $(n=81)$

\begin{tabular}{lll}
\hline Years of company established & Frequency & Percentage (\%) \\
\hline$<5$ years & 15 & 18.5 \\
5 - 10 years & 18 & 22.2 \\
10 - 15 years & 18 & 22.2 \\
$>15$ years & 30 & 37.0 \\
\hline Total & 81 & 100.0 \\
\hline
\end{tabular}

Table 1 shows the range for the years of the respondents' company. There are about four (4) ranges of years listed in the company particulars form. The purpose of this question is to identify the level time experience of the respondents' company do achieved in construction industry. Based on the returned questionnaires, it is found that the highest percentage of the established years is more than 15 years with the percentage of $37 \%$ out of $100 \%$. The range of years between 5 to 10 years and 10 to 15 years of company establishment do share the same percentage which are both $22 \%$ and considered to be the second highest respondents. The least numbers of respondents are from the company that been established less than 5 years. It is due to the facts that most of the respondents are from the company that had been in the construction industry for a long time and considered to have lots of experience especially involved with the management tools that will create a value for money for the project.

Table 2 : Company Experience in VM $(\mathrm{n}=81)$

\begin{tabular}{lll}
\hline $\begin{array}{l}\text { Company have } \\
\text { experience in VM }\end{array}$ & Frequency & Percentage (\%) \\
\hline Yes & 51 & 63.0 \\
No & 30 & 37.0 \\
\hline Total & 81 & 100.0 \\
\hline
\end{tabular}


Based on the results from Table 2, it shows that, the numbers of company that do have experience in Value Management process. It is found that $63 \%$ of the respondents claimed that their company have an experience in practicing Value Management and only $37 \%$ declare that their company does not have any experience and not practicing the Value Management in their construction project. This situation indicates that majority of the developer's company have an experience even a basic knowledge regarding Value Management process.

\subsection{Developer's Level of Awareness on Value Management Practice}

This question was aimed to determine the level of awareness among the staff which is eventually represent the company regarding the Government in the $10^{\text {th }}$ Malaysia Plan which had enforced that the Value Management practice should be done on the project over RM50 million.

Based on the obtained result in Table 4.3, the result shows that the score mean (4.00) is actually between the scale rating of 4.50 to 5.00 which represent the entire answer to be agreed with the statement of the company to aware with the $10^{\text {th }}$ National Plan regarding the Value Management process should be implement in the project over RM50 million. This result shows that most of the company aware with current issues especially issues of VM in construction industry.

For the statement Company top management support the staff in understanding VM recorded that, the score mean is 3.96 and represent the results to be slightly agree. The score mean tell us that, the respondents slightly agree that the company top management is concerned with Value Management process and have the attitude of supporting the staff in understanding Value Management process.

Table 3: The Level of Awareness on Value Management Practice ( $\mathrm{n}=81)$

\begin{tabular}{lll}
\hline Section & Statement of Awareness & Mean \\
\hline 1 & $\begin{array}{l}\text { Company aware with RMK-10th plan regarding the VM process for } \\
\text { project over RM50 mil. }\end{array}$ & 4.00 \\
2 & Company top management support the staff in understanding VM. & 3.96 \\
& & 3.91 \\
3 & Understanding of meaning and function of VM. & 3.89 \\
5 & Company have VM Guidelines for VM process. & 3.83 \\
6 & Company provide sufficient Information regarding VM to staffs. & 3.81 \\
7 & Company provide the staffs with VM Guidelines. & 3.81 \\
8 & Company professionals do attend seminars regarding VM. & 3.70 \\
9 & Company concerned with VM and do organize training among staffs. & \\
10 & Having in-house training for VM. & 3.57 \\
\hline AVERAGE & MEAN & 4.22 \\
\hline
\end{tabular}

Score mean for the statement of company recognize the benefits of VM is 4.22 and it is between the ranges of 4.50 to 5.50 which represent the results to be agreed with the statement. It is due to the fact that most of the company does recognize the benefits of implementing VM process throughout the building development study. It is a positive sign for the Value Management to be highly used in Kelantan state as the awareness towards its benefits had been highly recognize by the construction industry members.

Results from Table 3 also indicates the score mean for the statement of having in-house training for $\mathrm{VM}$ is 3.57 for which represent the whole answer also to be slightly agree. Based on the result, we can say that most of the respondents are aware with the involvement and existence of Value Management in the construction industry. 
Referring to the average mean of the results for the whole statements, 3.87, it can be summarized that the level of awareness amongst the developers towards Value Management Practice in Malaysia especially in Kelantan State had been established. This statement is supported by [3] it was also found that $63 \%$ of respondents did possess a good level of understanding towards the VM concept by the quality of feedback gathered from the questionnaire.

\section{Conclusion}

The aim of this research paper is to identify the level of awareness towards Value Management practice amongst the construction developers in Kelantan State. A broad literature review has provided some findings of the previous research conducted in order to find the level of awareness towards Value Management practice amongst Malaysian construction developers. The level of awareness towards Value Management practice amongst the Construction developers in Kelantan State has been successfully identified and the results indicate that average mean score for each question is 3.87 which concluded that they are aware of the existence and the issues of Value Management in Malaysian construction Industry but still face some barriers to implement it. Future research papers will report on the identification of the barriers and facilitating factors in implementing and practicing VM in Malaysia.

\section{References}

1. New South Wales Treasury (2004). Value Management Guideline. Total Asset Management, 118.

2. Jaapar A. (2006). Value Management Study to the Malaysia Construction Industry, 1-13.

3. Jaapar A. \& Prof. Dr. Victor Torrance J. (2006). Contribution Of Value Management To The Malaysian Construction Industry: A New Insight. In International Conference on Construction Industry.

4. Kelly, J. R., S. Male, et al. (2004). Value Management of Construction Projects. Blackwell Science Publishing.

5. Ong H.T. (2003). Quality and Value Management in Construction 'Achieving Excellence through Value-Managed Quality System (VMQS)’, Instituition Surveyor Malaysia.

6. Che Mat M.M. (1999). The Challenges And Potential Of Value Management In Local Construction Industry. Jurnal Alam Bina, 41-47.

7. Bowen P., Cattell K., Edwards P., Jay I. (2009). Value management practice by South African Quantity Surveyors. Emerald Journal.

8. Jaapar A., Endut I.R., Ahmad Bari N. A., Takim R. (2009). The Impact of Value Management Implementation in Malaysia, Journal of sustainable Development, 2(2). 